\title{
RESEARCH
}

Open Access

\section{Cost aggregation in export logistics chain}

\author{
Esa Hämäläinen ${ }^{1 *}$ (D) Elen Twrdy ${ }^{2}$ and Tommi Inkinen ${ }^{1}$
}

\author{
* Correspondence: \\ esa.hamalainen@utu.fi \\ ${ }^{1}$ University of Turku, Brahea Centre, \\ Centre for Maritime Studies, Turku, \\ Finland \\ Full list of author information is \\ available at the end of the article
}

\begin{abstract}
This paper analyses cost aggregation in a supply chain. It provides a literature overview on the key concepts of cost aggregation, multimodal transport, logistic chain and maritime transport. The focuses on the value adding process with logistics data and assesses the costs accumulation during the transport process. The paper also reveals multimodal impacts on the logistics costs. The research data is obtained from the costing system of a large export company. The company exports round $90 \%$ of its production and mostly to the European markets. The research data contains a sample of 929 invoiced orders to the largest market of the mill. The research results indicate empirical evidence of the cost-function properties. This type of an approach is rare in logistics literature as these detailed data sets are highly difficult to obtain. The article concludes by addressing future research task and directions.
\end{abstract}

\section{Introduction}

Multimodal logistics including maritime transport and port handling is always a challenge for freight owners, because it has impacts on both the costs and delivery time. Sea transport is in an essential role for most of the countries that are dependent on trade. Porter (1990) introduced the diamond model to examine industry competitiveness. Aiginger (2006) also studied international competitiveness between nations and he accepted the Diamond Model. The Diamond Model simply covered four selected attributes that determine the competitiveness of a country or an industry at microeconomic level referring to 1 . supply of skilled labour and/or infrastructure, 2. demand conditions, 3. supporting industries and 4. firm strategy, structure, and rivalry. Porter did not highlight the meaning of logistics as an implication as a part of his Diamond Model. Analogically Krugman (2017) and Aiginger (2006) addressed the importance of logistics as a supporting element in efficient economics. The purpose this study is to present a detailed view of costs in maritime logistics environment from export perspectives. Huemer (2012) argues that the integration of manufacturing and logistics are important extensions in the functions of an export dependent industry (e.g. Pagh and Cooper 1998). Eckhardt and Rantala (2012) address that logistics makes trade and globalization possible offering efficient methods for moving raw materials and end products extensively. Freight movement rates generate constant discussions inside export companies; how are these costs composed and how do they impact profitability and also, how do they affect competition conditions of export companies? Engblom et al. (2012) reveal that, on average, logistics costs constitute a considerable proportion of operating costs, often more than $10 \%$ of the company's turnover. Accordingly, Hämäläinen (2011) exposed that in the

(c) The Author(s). 2017 Open Access This article is distributed under the terms of the Creative Commons Attribution 4.0 International License (http://creativecommons.org/licenses/by/4.0/), which permits unrestricted use, distribution, and reproduction in any medium, provided you give appropriate credit to the original author(s) and the source, provide a link to the Creative Commons license, and indicate if changes were made. 
Nordic paper industry the share of total logistics costs from the turnover varies significantly between customers and can be even up to $20 \%$ of the turnover on customer level.

Manufacturing companies in distant locations must utilize obligatory intermodal transport functions to get their products to the customer. Normally, Short Sea Shipping (SSS) lines from Nordic export ports operate according to weekly timetables. These make fast and direct deliveries impossible and there is a need for local service warehouses close to the consignees. De Oliveira (2014) notes that any attempt to improve the integration of a country into the international trading system should consider the effects of the transport costs and their determinants. In multimodal logistics, handling every stage increases costs variously and depending on the nature of the logistics phase, e.g. port handling and lifting, transportation or warehousing (also Inkinen and Tapaninen 2009).

Efficient supply chain in maritime environment obliges that shipping and port connectivity is optimized with the remote areas. When a large bulk company delivers hundreds of thousands of tons of finished products annually to the market, this phenomenon requires accurate coordination and communication with the third-party transport operators during the whole chain. Openness, like sharing of best practices in the transport sector, could support the process improvements and the development of efficient logistics models for all partners from the remote areas to the end customers (also ChangKeun et al. 2017). Anderson and van Wincoop (2004) note that it is rather laborious to identify and measure the real trade costs generated from deliveries between countries. The longitudinal case data from an export company somewhat unwraps this complexity of logistics research (Hämäläinen 2011; 2015). Logistics and transportation rates change over time and, furthermore, the manufacturing costs compared to competitors have an impact on the export performance. Davis and Weinstein (1999) and Krugman (1991), who have developed industrial location models, have argued that the freight movement costs have an essential role when companies are looking for a favourable location. Efficient connections from remote areas to the markets must be taken into account when location decisions are discussed and made.

The main research tasks of this paper are: 1) To reveal the value adding process with detailed logistics data. 2) To expose the ways in which the logistics costs accumulate during the transport process. 3) To provide a clarification on how the SSS impacts the logistics costs to main markets. All three points have been rather scarcely discoursed previously in research papers (see also Albornoza et al. 2016). We also highlight the warehousing costs during the transport, but we exclude the research the capital costs produced by extra warehousing. We did not acquire the necessary information about this issue from the source data. The authors will reveal the variety in export supply chain in the case of one supplier that serves many customers. According Martincus et al. (2014) heterogeneity may arise from several reasons, like from the knowledge of markets, efficiency of supply chain, from product pricing skills or delivery accuracy. They address that the essential issue is that many of the supplier (seller) to buyer characteristics are possible to unveil only with very detailed real data.

The structure of this paper is as follows. Theoretical ideas regarding port and shipping logistics, which contributed to composing this paper, are presented in Section 2. In Section 3, we take a closer look on how data was acquired and which research methods were used in the study. The detailed findings based on the empiric data analysis are presented in Section 4. Discussion and conclusions are compiled in Section 5. Ideas for future research drawn from this study are presented in Section 6. 


\section{Background of port and shipping bound logistics}

Tae-Woo Lee and Venus Lun (2016) note that shipping and port operations facilitate the scale economy in production and global shipping. Much of the positive economic development in the Nordic countries is associated with the efficient integration of maritime transport and port operations. Normally, a maritime transport system consists of ports, logistics service operators and carriers, which connect export and import ports with regularly scheduled shipping lines. The remote area connections are operated by truck or rail logistics. This supply chain, including 24/7 manufacturing, needs to have continuous detailed planning of deliveries. The Nordic export industry ports play an important role in connecting remote areas to the world market. Álvarez-SanJaime et al. (2013) point out that the road transport sector does marginal cost pricing, whereas the shipping companies hold market power and enjoy economies of scale. Vaghi and Lucietti (2016) analyzed with a case study that it is possible to gain a significant amount of potential by decreasing the dwell time for containers in ports by speeding up of formalities. The simplification of customs procedures brings benefits for the transport time and costs. This type of research needs very detailed case data from an export company and from logistics service providers. Official public statistics do not offer detailed information.

Porter (1985) defined value chain as integrated activities produced by the firm together with logistics service providers to create the product or service required by the customer. As a result, Porter's ideas increased outsourcing of those activities in which the organization does not have a clear competitive advantage (see e.g. Havenga and Zane 2016). This integrated value-creating process is commonly known as the value chain. Havenga and Zane (2016) address that together with the advent of the information and communication technology revolution heralded a new era for supply chain management as the management of a network of connected and interdependent organizations mutually and cooperatively working together in preferred alliances to control, manage, and improve the flow of materials and information from suppliers to end users (Christopher 2011; Inkinen et al. 2009; Makkonen et al. 2013). Gattorna (2010) refers to this as dynamic value networks. New information increases the accuracy of value chain, demanding complicated algorithms for calculations. Crainic and Kim (2007) define multimodal maritime freight transport to include loading at the port, transportation from its origin to its destination, including a sequence of at least two transportation modes and the transfer from one mode to the next being performed at an intermodal terminal. Growing global free markets, including marine shipping and port operations, have made a properly working logistics chain an important topic for business success. Anderson and Van Wincoop (2004) remind that transport expenses are a fundamental part of trade costs. Findings of several studies address that service quality, like the frequency of services, may have an impact on freight rates (Wilmsmeier et al. 2006; Martinez-Zarzoso and Nowak-Lehmann 2007).

Well-functioning connections between export and import ports play an essential role in logistics chains, particularly in the export bound Nordic countries, where export companies heavily utilize the SSS transport routes. Negative impacts of long transport routes can be reduced significantly by efficient manufacturing and logistics chains, but still extra transfer costs remain (Hämäläinen 2011) compared to local competitors that are close to the customers. Wang et al. (2016) emphasize the importance of port 
connectivity to the entire logistics chain of maritime transport, as well as the need to identify a cost-efficient way to facilitate international trade. Turkensteen and Klose (2012) highlight that the geographical dispersion of demand has a direct influence on the placement and the number of warehouses (see e.g. Hämäläinen 2011). These warehouses act as service centers for local customers producing extra transportation costs and increasing inventory levels (binding extra capital); see also Langevin et al. (1996). Transportation expenses are generally assumed to be a function of the travel distance; see Daganzo and Newell (1985), Daganzo (2004). Daganzo and Newell (1985) formalize a relationship between logistics costs and travel distances. From a Nordic manufacturer, in one-to-many distribution systems, costs are aggregated per item as a function of the travel distance and the stop density. The stop density depends on the number of loadings, dispatches and intermodal transport hubs. Truck - port - truck service center (warehouse) - truck to customer has several stops from hours up to days. Wang and Cheng (2009) have exposed that the inventory cost function can be unified into a common expression for various batching schemes.

The overall cost of the cargo's transport covers the ship cost, port loadings, remote are transportation cost and inventory cost between intermodal movements. Tang et al. (2011) indicate with empirical data that port efficiency is the most important factor that attracts customers. Pallis et al. (2011) revealed that the reasons behind choosing a port have been studied in 56 studies during 2007 and 2008, especially from the perspectives of logistics activities in seaports and their shipping connections. Notteboom et al. (2013) found 27 studies since 1973 published in the Journal of Maritime Policy \& Management that highlight the role of ports in transport and supply chains. Robinson (2002) pointed out that ports serve as the essential element in the value-driven chain systems. As a service provider in a supply chain, a port connects producers and consumers through import/export trade. The consolidation of a port's function through vertical and horizontal integration along the supply chain has been used to assess the port's competitiveness and overall efficiency. Structural changes, such as outsourcing production components to a supplier network and integrating the functions of production, transportation, warehousing and distribution in logistics, has become popular issues in present studies (Notteboom and Winkelmans, 2001). Twrdy et al. (2012) point out that ports are an important part of supply chains and that today whole supply chains compete among themselves, not just ports.

Magala and Sammons (2008) address that port users choose a port-oriented supply chain in which the port is embedded as a critical element. Configurations of shipping routes and networks provide a direct assessment of port connectivity, representing a port's competitiveness (Low et al. 2009). Export industry ports are a part of a valuedriven chain system competing with other value-driven chain systems (Robinson 2002). Bichou and Gray (2004) and Marlow and Paixão (2003) address that ports are an essential component of integrated supply chains. Tran (2011) highlights that the selection of a port is based upon the minimization of the overall cost of the cargo's journey. Economic efficiency of logistics service providers has an important role in that journey. Freight logistics developers have used clustering to understand the geographic distribution of demand and simplify logistics operations (Cao and Glover 2010; Sharman and Roorda 2011; Singh et al. 2007; Qiong et al. 2011). Some researchers argue that competition has shifted from competition between companies towards competition 
produced through supply chain and practical logistics management (e.g., Ketchen and Hult 2007). It is clear that efficient logistics give a chance for the manufacturer to operate in the global market and reach more customers. Bhatnagar and Viswanathan (2000) and Bhutta et al. (2003) remind that operating in a global market may also increase the uncertainty in the company's operations. Long transport routes may lead to increased inventories and longer delivery times of freight transport and bond capital. However, warehouses close to customers serve local customers and from the view of the customer, delivery times are not long. Producers are filling the warehouses in advance with correct product assortment ordered by customers to fill their needs. Researchers remind that location of an industry naturally has an impact on the success and survival of a production unit. For example, Carbone and De Martino (2003) emphasize the importance of a common platform among both the logistics systems and the cargo handling systems to create synergies and to combine the interests of all actors. Accordingly, Pettit and Beresford (2009) point out the change of port's roles in supply chain from the low value adding in the 1960s, to the integration into trade and transport chains in the 1990s and to the vertical integration with global logistics services providers in the 2000s. A significant increase in global freight volumes since the 1990s has encouraged ports to actively invest in efficiency, capability and flexibility, especially in container handling, to serve all parties of logistics partners (see e.g. Yang and Chen 2016; Alessandria and Choi 2014). Porter (2000) notes that the value chain includes all the activities that a firm requires to collect, store and distribute the finished products, including the logistics chain from the mill to the customers. In this value chain the ports have a crucial role now and evidently in the future, although the comments of some leading politicians have considered free trade as a threat to domestic and local manufacturing.

\section{Research data}

In executing an analysis of the multimodal transport costs, the main issue is to obtain reliable data (Martinez-Zarzoso and Suarez-Burguet 2005). When using official statistical data (e.g. International Monetary Fund) as a proxy of transport costs (Baier and Bergstrand 2001; Limão and Venables 2001) there is a chance that data are distrustful due to differences when operators collect this information (see e.g. Hummels and Lugovskyy 2006). Hummels (2007) remind that product-level transport data are available for some countries in open official statistics. In this paper, the authors exploit logistics freight rates that were invoiced from customers, covering inland transport, port handling and extra warehousing rates (see e.g. Limão and Venables 2001; Wilmsmeier and Hoffmann 2008). Firm-level data on transport costs are practically nonexistent (e.g. Bernard et al. 2006) and the endogeneity problems are foreseeably heavy. These abovementioned challenges address that case-type studies are relevant in the transport and logistics cost studies. The buyer-supplier relationships are expressed according to their genuine and industrial contexts (Goffin et al. 2006).

Our research data is obtained from the paper mill's integrated cost management system (see e.g. Hämäläinen 2011). This confidential data was intended for research purposes. In the paper industry, machine reels are converted, according to customer specifications, either into standardized sheets or unique customer rolls. After converting, products are packed and put in the warehouse and dispatched later in a particular 
order. The research mill sells $90 \%$ of its production, printing paper qualities, particularly to European markets and this is done by truck - ship - truck multimodal chain. This long transport chain increases the variety between markets. Every industry has unique transport and supply patterns, but possible similarities can be exposed between bulk industries.

The data covers a sample of 929 invoices, thus, all delivered orders from one month (June 2009) from the mill to the most important market (country). From the invoices, we acquired logistics data after the mill warehouse: delivered tons, port handling costs, total transport costs, share of short sea shipping costs of transport costs, land transport, warehousing costs and also the aggregation of the supply chain costs. June 2009 was a normal month in paper production and deliveries. The mill produced paper normally year-round in 2009. The data was collected in collaboration with the company and it is confidential except to the presented aggregated results. The data set may be considered unique and highly difficult to obtain as it reveals cost structures of the company. These are core business information and therefore too often out of reach of academic research.

Our purpose was to use all the relevant logistics information from the invoices. Methodologically we apply aggregation and correlation visualizations in order to present the cost accumulation curves presented in Figs. 1, 2, 3 and 4. The sample uncovers evident and interesting logistics variations between customers. MartinezZarzoso and Suarez-Burguet (2005) point out that many studies note that firm-level logistics cost data is rarely available. In the following section, we will point out rarely examined features concerning logistics costs and their behavior in the export logistics environment with the help of our detailed data.

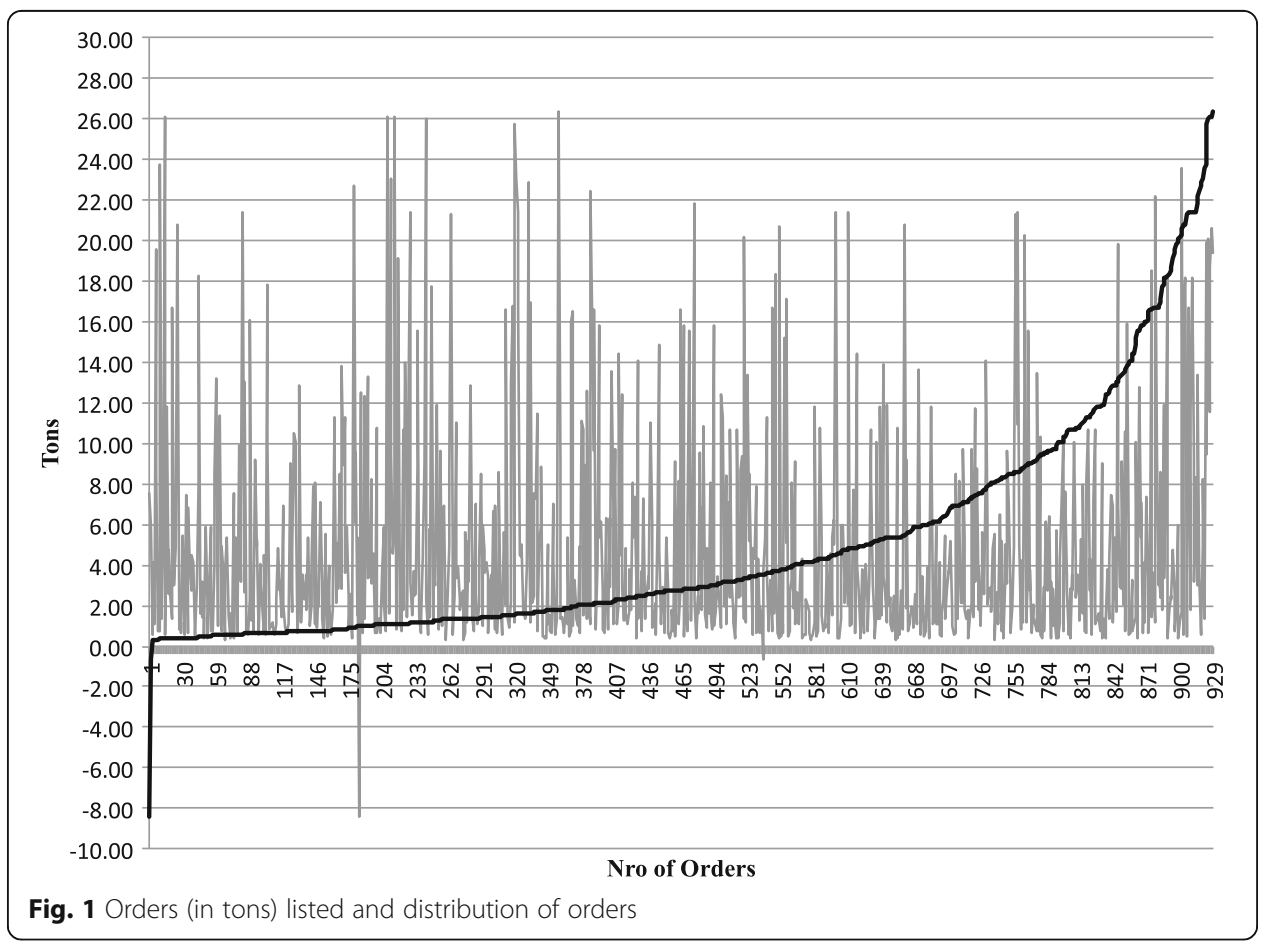




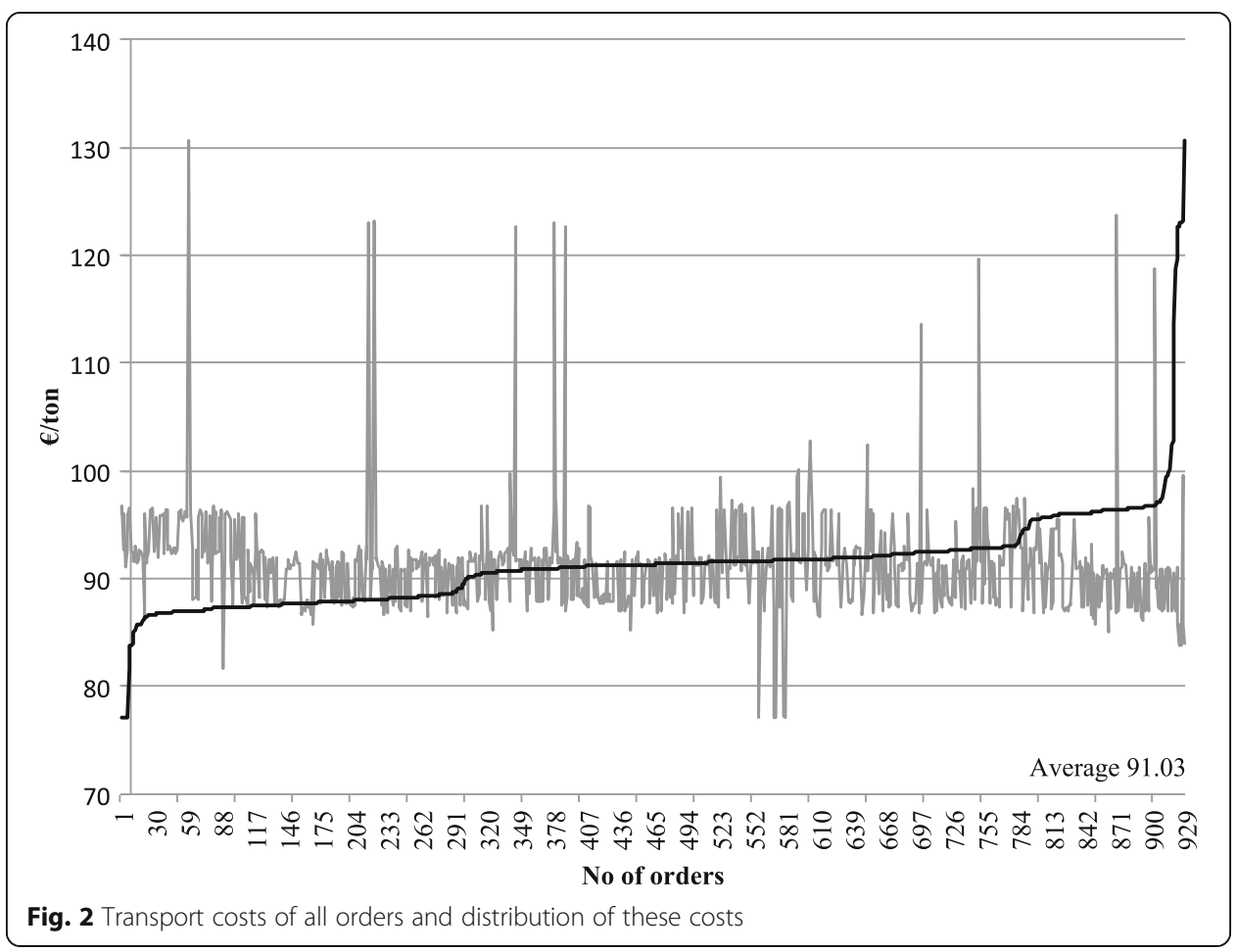

\section{Findings}

This study contributes to the logistics research with detailed empirical data. We expose how the logistics costs aggregate during the voyage from the mill gate to the customers in large foreign market. We address that the results of this study are bound to paper or bulk industry. In this section, we will show the results that






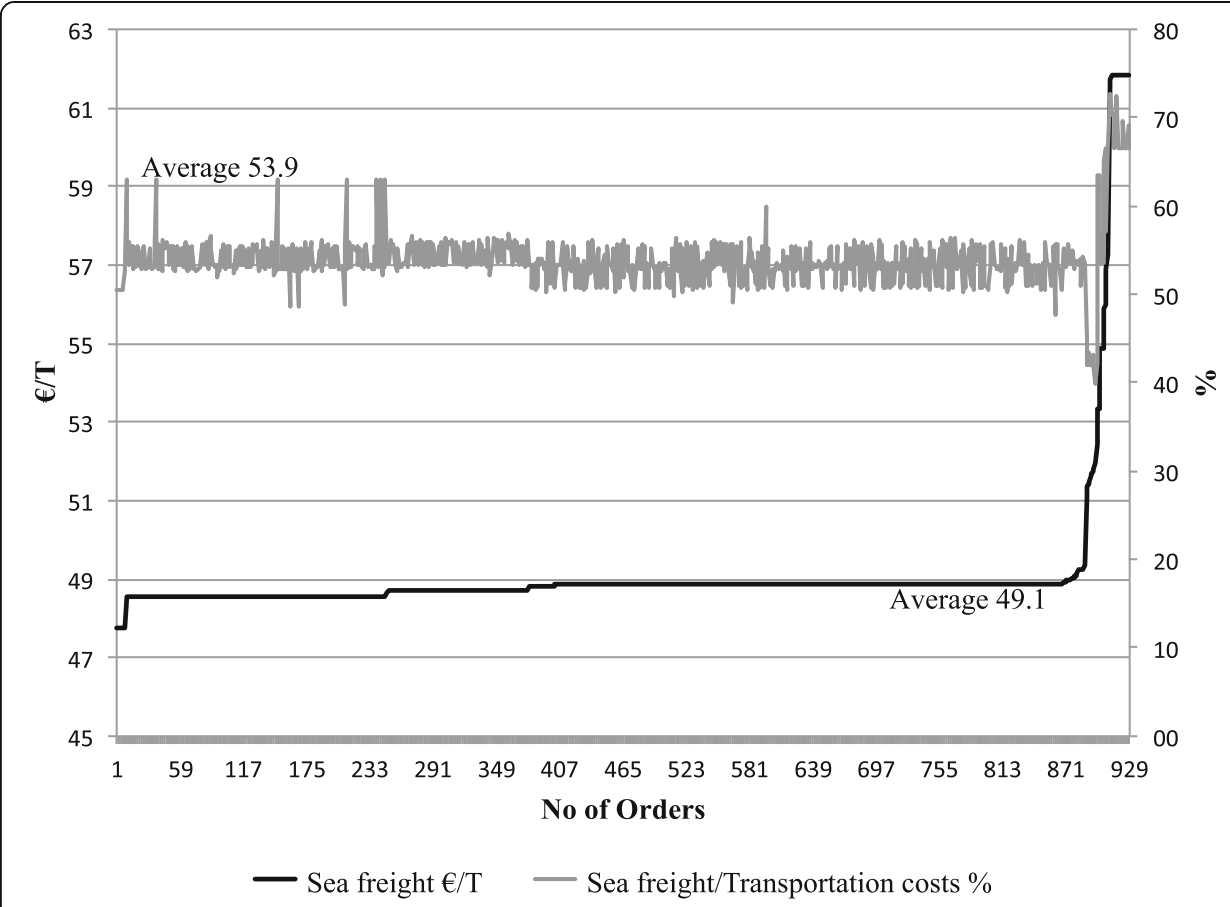

Fig. 4 Average Sea Freight $€ / T$ and their share of total transport costs (\%)

are based on the mill data. The first research task defined as "to reveal the value adding process with detailed logistics data" is discussed in the following.

Figure 1 lists the order volumes and also distribution or orders from the smallest to the largest. The distribution of orders is relatively normal and the orders are divided rather evenly between the smallest and the largest amounts. The distribution is listed according to invoice numbers during 6/2009. Fig. 1 addresses that the orders are rather small in tons: over half of the deliveries are under 5 tons. The smallest orders were only some hundred kilos and the largest were up to 26 tons. The figure reveals an interesting factor about the business and logistics character of a paper mill: a large unit can manufacture about 500,000 tons of paper annually. If orders are from 2 to 25 tons, on average, around 5 tons, there can be roughly between 20,000 and 50,000 annual international deliveries and between 1500 to 4000 monthly deliveries. This addresses the importance of logistics for bulk industry in getting the products to the customers in good shape and in time.

The firm-based data address that total transport costs from the mill to the end customers vary significantly, as Fig. 2 shows. Hummels and Skiba (2004) and Hummels et al. (2009) came to the same conclusions: export costs vary endogenously with trade, and the adoption of new transport technology usually lowers the transfer costs of specific products. Fig. 2 indicates that some of the export deliveries are transported either with lower prices than on average $(91 € / \mathrm{T})$ or much more expensively. These price variations are dependent on much these expensive deliveries in $€ / T$ may consists both smaller packages of paper and many intermodal stages. In this study, euro can be understood as a unit that varies over time. The large differences in costs exist between customers. The export 
transportation costs vary from $75 € /$ ton and up to $130 € /$ ton. These sums include transports from the mill to port, all port operations, domestic and foreign warehousing, sea freights, transport from import port to customers and the insurance.

The costs are rather predictable because normally the paper mills make long term agreements with logistics operators. The products are usually transported further to customers from a port that is located closest to the mill. The ro-ro vessels normally visit the port of export weekly or even more often, and carriers transport the products to an agreed port of export. From the port of import, the packages are transported either directly to customers or stored to service warehouses and from there, delivered later to the destinations.

Figure 3 presents a correlation between delivered volumes and costs in $€ / T$. Actually, it shows that there is no correlation between costs in $€ / T$ and transported amounts. Figure presents that delivered tons of orders and their costs in $€ / T$ have no real causality. Small amounts can have lower costs and bigger deliveries can have higher or lower costs in $€ / T$. This result is rather interesting, because it could have been assumed that larger transported volumes cost less in $€ / T$.

The second research task was defined as "to expose the ways in which the logistics costs accumulate during the transport process" and it is analysed and discussed in the following: Nordic mills must always use sea transport to deliver products to overseas markets. Delivered volumes are large, millions of tons in total. The connectivity to all ports of import is a key factor (see e.g. Low et al. 2009). The variation of the sea freight costs according to the obtained 929 invoices to one export country is presented in Fig. 4. It shows that the freight prices are rather constant, which means that evidently, the freight owner does not have much bargaining range. The logistics routes and multimodal chains can be different even though the delivery country or location is nearly the same. Usually, there is several the port of import, which can locate closer to the port of export. In such case the land transport may be longer and costs can rise. The share of sea freight is normally over $50 \%$ of the total transport costs, addressing that the distance matters. It must be considered as an issue that should be carefully planned and budgeted beforehand. The mills are in operation round-the-clock and produce hundreds of tons of finished and packed products. The supply chain planning is in the center of operations, in order to have deliveries manufactured and transported according to customer expectations. This integrates the suppliers' and customers' value adding chains. These should be in synergy to support economic effectiveness in both units. Fig. 4 shows that per cent of sea freight of total transport costs is $54 \%$ on average and some variation exists. Sea freight rates are around $49 € /$ ton and in some few cases up to $75 € /$ ton.

Firm-based supply chain information is valuable because it comes from real functions bringing also accuracy for research. For a researcher, this is an exceptional occasion to analyze the accumulation of costs and the level costs in different phases in detail. Fig. 5 reveals how the total costs of the transport and logistics chain are accumulated in the most essential costs points during the freight transport. Fig. 5 addresses that the transport from the mill to customers adds costs in every phase very differently. The content of the figure should be read by starting from the bottom. Truck transport, port handling and loading highlights the freight transfer from the mill warehouse to the port and loading into the vessels at the port. The share of these costs is about $9 \%$ of total 


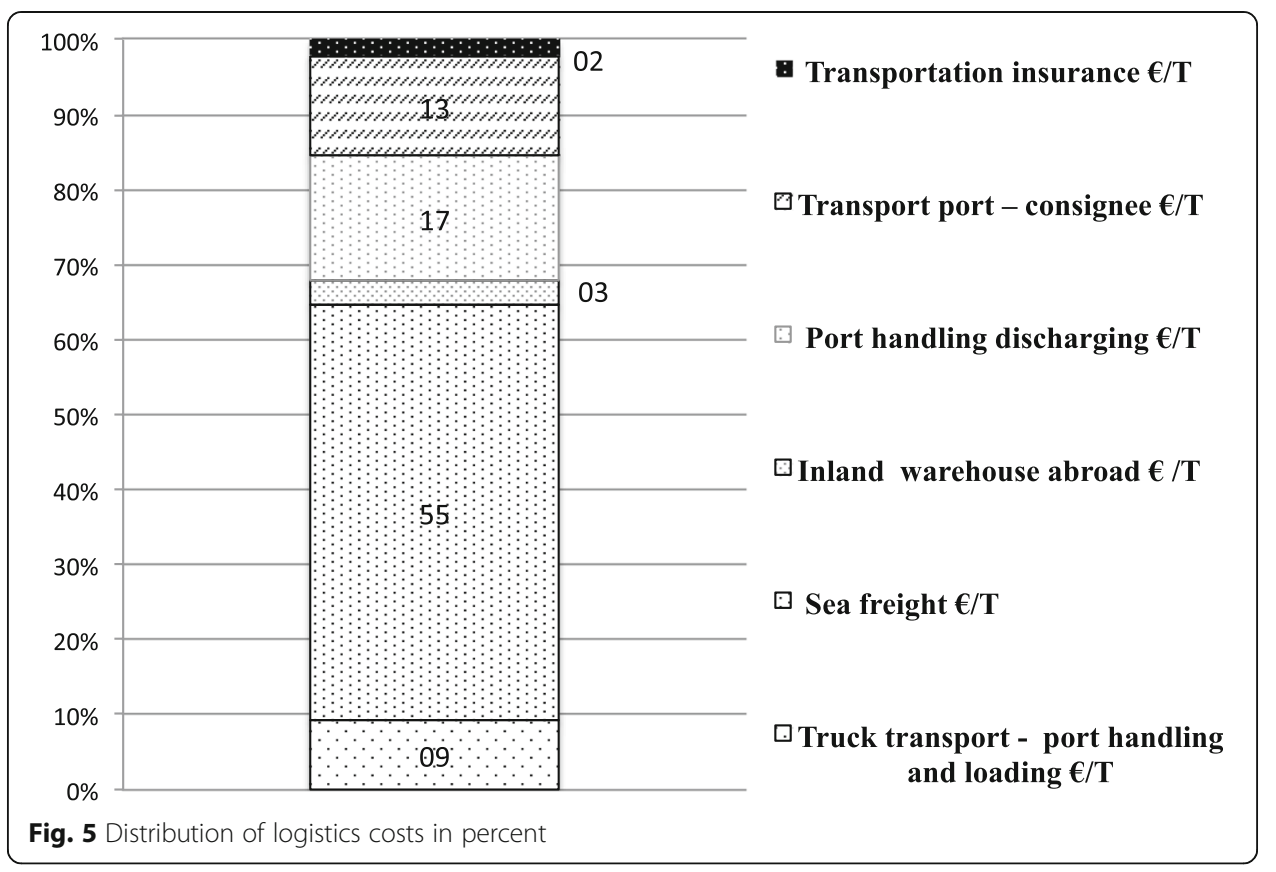

transport costs. On average, the total transport costs were about $91 € / \mathrm{T}$, so the land transport and vessel loading are about $10 € /$ T. Sea freight is the following cost stage covering the SSS transport and its share is over 55\% (about $60 € / \mathrm{T}$ ) of total transport costs. Inevitable sea freight rates have significant effects on the cost accumulation of the total transport. High sea freight costs may depend on the lack of competition between the shipping companies in SSS routes. Genuine competition is scarce between shipping operators. After sea transport the following cost components are port handling, intermediate warehousing and transport to the consignee. These costs are together approximately $35 \%$ including insurances. Together these costs make about 39€/T.

The transport and warehousing costs for export industry are obligatory costs that must be covered by other competitive means like efficient machinery, product automation, better product quality, thus, higher prices etc. However, especially in the bulk industry, price competition is tough. Mills located far from the markets must have productive and efficient machines to mitigate long transport costs that can be up to 10 times higher than in the mills located close to the customers (see e.g. Hämäläinen 2011).

The final research task set for the paper was defined as "to provide a clarification on how the SSS impacts the logistics costs to main markets". In order to answer this Fig. 5 explains the distribution of different costs elements in relation overall costs. The study results imply that the manufacturing units located behind sea transport routes must continuously plan and negotiate with logistics service providers about possible improvements of logistics technologies. The exported volumes are so large that the logistics channel must continuously function properly. The production units far from markets are often under closer and critical look from the perspective of the firm management. Affordable manufacturing locations are often relatively close to buyers. However, during the latest decades, efficiency of logistics has developed tremendously. Large container ships that carry 
up to $18,000-22,000$ TEU have clearly reduced transport unit costs in over sea routes. Accordingly, SSS cargo shipping in Europe provides effective ways for remote companies to stay in business.

\section{Conclusions and discussion}

This paper has revealed the aspects of logistics in export industry in a case in which a company uses multimodal maritime transport in freight movement. The researchers discussed the impacts of logistics rates on the competition of export companies located far from the markets. When a manufacturing company in a Nordic country exports products to central Europe, the products go through intermodal terminals. For this study, we obtained confidential data from a large export company. The origin of our data is from the mill's advanced cost management system. The company exports about $90 \%$ of its production and mostly to European markets. The research data contains a sample of 929 invoiced orders from June 2009 to the largest market of the mill. The data had detailed numbers on delivered amounts, port handling costs, all transport costs, share of sea costs of total transport costs and truck transport. The authors were able to reveal the accumulation of costs after the packages left the mill. The research data was normally distributed. The data addressed that variations exist between customers. The supply chain routes can vary even if the delivery country is the same. A clear limitation of this study is that the data covers only the supply chain to one export country so the variations between larger different markets were not revealed. Also, the timespan of the research was short, only one month, and the development of the logistics streams was not possible to analyse. However, because of the detailed data of 929 invoices and deliveries, this study gives a revealing frame of how logistics of bulk industry operate. The delivered volumes are rather small.

The share of sea logistics rates is over $50 \%$ of the total transport costs and when adding port-handling as sea bound costs, the maritime transport costs are between 70 and $80 \%$ of total transport costs. Our study highlights the complexity of export logistic because there are several critical and moving components. These separate logistics sections must be integrated seamlessly to avoid disruption in deliveries. As a summary, this paper reminds that at manufacturing sites located far from the markets, logistics is a daily concern. Paper industry (including pulp and board) is highly important for Nordic countries giving work for hundreds of thousands of people. Therefore, logistics, among other factors (Porter 1990), is an extremely important factor from the perspective of national competitive position. Obviously, Nordic paper mills have succeeded to solve this logistics puzzle in an excellent way, because the Nordic countries still produce and export a relatively large share of forest industry products consumed in Europe.

The study provided a number of academic and practical implications. First, it shows that cost modelling in transport requires different types of industry data sets and extensive quantitative analyses. Second, the results opening for new methodology development. For example, combination of various data sets, similar to what we have use here, and their covariance analysis could provide a rigid insights to differentiation between these industries. This is one of the future research challenges. Practical implications include communication of this type analysis results to the industries. Companies themselves carry out cost surveillance but they lack information on 
classifications and broader industry situations from other fields. This research also opens up knowledge concerning potential efficiency gains.

\section{Limitations and future research}

This paper exposed a transport costs structure with exact invoice data to one country. This is also a limitation of the study and it cannot be totally verified to represent the situation in all companies operating in the same industry field. However, the case data presented is obtained from a significant export company and we consider that similar companies probably have similar cost structures. However, to verify this hypothesis, additional data from similar (and dissimilar) companies and industries are needed. In the future, studies could also focus more on explicit locations of customers and how the costs vary. This will open a new window to micro level research of supply chains. The firm based case studies have naturally limitations because the research data is often based on one source, but still these studies give a contribution to pure theoretical modelling in logistics discussions, especially with concrete numbers. Therefore, there exists still a need of combining theoretical modelling into large cost data sets.

Authors' contributions

EH and ET created the research design. EH, ET and TI wrote the paper. All authors read and approved the final manuscript.

Competing interests

The authors declare that they have no competing interests.

\section{Publisher's Note}

Springer Nature remains neutral with regard to jurisdictional claims in published maps and institutional affiliations.

\section{Author details}

${ }^{1}$ University of Turku, Brahea Centre, Centre for Maritime Studies, Turku, Finland. ${ }^{2}$ University of Ljubljana, Faculty of Maritime Studies and Transport, Ljubljana, Slovenia.

Received: 27 June 2017 Accepted: 14 November 2017

Published online: 23 November 2017

\section{References}

Aiginger, K. (2006). Revisiting an evasive concept: Introduction to the special issue on competitiveness. Journal of Industry, 6(1), 63-66. Albornoza, F., Fanellic, S., \& Hallak, J. C. (2016). Survival in export markets. Journal of International Economics, 102(2), 262-281.

Alessandria, G., \& Choi, H. (2014). Do falling iceberg costs explain recent U.S. export growth? Journal of International Economics, 94(2), 311-325.

Álvarez-SanJaime, Ó., Cantos-Sánchez, P., Moner-Colonques, R., \& Sempere-Monerris, J. J. (2013). Competition and horizontal integration in maritime freight transport. Transportation Research Part E, 51(1), 67-81.

Anderson, J., \& van Wincoop, E. (2004). Trade costs. Journal of Economic Literature, 42(3), 691-751.

Baier, S. L., \& Bergstrand, J. H. (2001). The growth of world trade: Tariffs, transport costs, and income similarity. Journal of International Economics, 53(1), 1-27.

Bernard, A., Jensen, B., \& Schott, P. (2006). Trade costs, firms and productivity. Journal of Monetary Economics, 53(5), 917-937.

Bhatnagar, R., \& Viswanathan, S. (2000). Re-engineering global supply chains - Alliances between manufacturing firms and global logistics service providers. International Journal of Physical Distribution and Logistics Management, 30(1), 13-34.

Bhutta, K. S., Huq, F., Frazier, G., \& Mohamed, Z. (2003). An integrated location, production, distribution and investment model for a multinational corporation. International Journal of Production Economics, 86(3), 201-216.

Bichou, K., \& Gray, R. (2004). A logistics and supply chain management approach to port performance measurement. Maritime Policy \& Management, 31(1), 47-67.

Cao, B., \& Glover, F. (2010). Creating balanced and connected clusters to improve service delivery routes in logistics planning. Journal of System Sciences and System Engineering, 19(4), 453-480.

Carbone, V., \& De Martino, M. (2003). The changing role of ports in supply-chain management: An empirical analysis. Maritime Policy \& Management, 30(4), 305-320.

ChangKeun, P., Park, J., \& Choi, S. (2017). Emerging clean transportation technologies and distribution of reduced greenhouse gas emissions in Southern California. Journal of Open Innovation: Technology, Market, and Complexity, 3(8). https://doi.org/10.1186/s40852-017-0059-y.

Christopher, M. (2011). Logistics and supply chain management: Creating value-adding networks. Harlow: Financial Times Prentice Hall.

Crainic, T. G., \& Kim, K. H. (2007). Intermodal Transportation. In C. Barnhart \& G. Laporte (Eds.), Transportation, handbooks in operations research and management science (pp. 467-537). Amsterdam: North-Holland

Daganzo, C. (2004). Logistics systems analysis (4th ed.). Heidelberg: Springer Verlag. 
Daganzo, C., \& Newell, G. (1985). Physical distribution from a warehouse: Vehicle coverage and inventory levels. Transportation Research Part B, 19(3), 397-405.

Davis, D. R., \& Weinstein, D. E. (1999). Economic geography and regional production structure: An empirical investigation. European Economic Review, 43(2), 379-407.

De Oliveira, G. F. (2014). Determinants of European freight rates: The role of market power and trade imbalance. Transportation Research Part E, 62(1), 23-33.

Eckhardt, J., \& Rantala, J. (2012). The role of intelligent logistics centres in a multimodal and cost-effective transport system. Procedia - Social and Behavioral Sciences. Transport Research Arena- Europe, 48, 612-621.

Engblom, J., Solakivi, T., Toyli, J., \& Ojala, L. (2012). Multiple-method analysis of logistics costs. International Journal of Production Economics, 137(1), 29-35.

Gattorna, J. (2010). Dynamic supply chains. Harlow: Prentice Hall.

Goffin, K., Lemke, F., \& Szwejczewski, M. (2006). An exploratory study of 'close' supplier-manufacturer relationships. Journal of Operative Management, 24(2), 189-209.

Hämäläinen, E. (2011). Economic geographical analysis of the Finnish Paper Industry. Annales Universitatis Turkuensis, SER A11 - TOM, 263, Turku.

Hämäläinen, E. (2015). Estimated impacts of the sulphur directive on the Nordic industry. European Transport Research Review, 7(8), 13

Havenga, J. H., \& Zane, P. (2016). Freight logistics' contribution to sustainability: Systemic measurement facilitates behavioural change. Transportation Research Part D, 2016. https://doi.org/10.1016/j.trd.2016.08.035.

Huemer, L. (2012). Unchained from the chain: Supply management from a logistics service provider perspective. Journal of Business Research, 65(12), 258-264.

Hummels, D. (2007). Transportation costs and international trade in the second era of globalization. Journal of Economic Perspectives, 21(3), 131-154.

Hummels, D., \& Lugovskyy, V. (2006). Are matched partner trade statistics usable measures of transportation costs? Review of International Economics, 14(1), 69-86.

Hummels, D., Lugovskyy, V., \& Skiba, A. (2009). The trade reducing effects of market power in international shipping Journal of Development Economics, 89(1), 84-97.

Hummels, D., \& Skiba, A. (2004). Shipping the good apples out: An empirical confirmation of the Alchian-Allen conjecture. Journal of Political Economy, 112(6), 1384-1402.

Inkinen, T., \& Tapaninen, U. (2009). Finnish-Russian transport and business expectations. World Review of Intermodal Transportation Research, 2(4), 279-295.

Inkinen, T., Tapaninen, U., \& Pulli, H. (2009). Electronic information transfer in a transport chain. Industrial Management \& Data Systems, 109(6), 809-824.

Ketchen Jr., D. J., \& Hult, G. T. M. (2007). Bridging organization theory and supply chain management: The case of best value supply chains. Journal of Operational Management, 25(2), 573-580.

Krugman, P. (1991). Geography and trade. Boston: MIT Press.

Krugman, P. (2017). Ricardo's difficult idea. Available online at: http://web.mit.edu/krugman/www/ricardo.htm.

Langevin, A., Mbaraga, P., \& Campbell, J. (1996). Continuous approximation models in freight transport: An overview. Transportation Research Part B, 30(3), 163-188.

Limão, N., \& Venables, A. (2001). Infrastructure, geographical disadvantage, transport costs and trade. World Bank Economic Review, 15(3), 451-479.

Low, M. W. J., Lam, S. W., \& Tang, L. C. (2009). Assessment of hub status among Asian ports from a network perspective. Transportation Research Part A, 43(6), 593-606.

Magala, M., \& Sammons, A. (2008). A new approach to seaport choice modelling. Maritime Economics and Logistics, 10(1-2), 9-34.

Makkonen, T., Inkinen, T., \& Saarni, J. (2013). Innovation types in the Finnish maritime cluster. WMU Journal of Maritime Affairs, 12(1), 1-15.

Marlow, P. B., \& Paixão, A. C. (2003). Measuring lean ports performance. International Journal of Transport Management, $1(4), 189-202$.

Martincus, C. V., Carballo, J., Garcia, P. M., \& Graziano, A. (2014). How do transport costs affect firms' exports? Evidence from a vanishing bridge. Economics Letters, 123(2), 149-153.

Martinez-Zarzoso, I., \& Nowak-Lehmann, F. D. (2007). Is distance a good proxy for transport costs? The case of competing transport modes. The Journal of International Trade \& Economic Development, 16(3), 411-434.

Martinez-Zarzoso, I., \& Suarez-Burguet, C. (2005). Transport costs and trade: Empirical evidence for Latin American imports from the European Union. The Journal of International Trade \& Economic Development: An International and Comparative Review, 14(3), 353-371.

Notteboom, T., de Langen, P., \& Jacobs, W. (2013). Institutional plasticity and path dependence in seaports: Interactions between institutions, port governance reforms and port authority routines. Journal of Transport Geography, 27(1), 26-35.

Notteboom, T., \& Winckelmans, W. (2001). Structural change in logistics: How port face the challenges? Maritime Policy \& Management, 28(1), 71-89.

Pagh, J. D., \& Cooper, M. C. (1998). Supply chain postponement and speculation strategies: How to choose the right strategy. Journal of. Logistics Management, 19(2), 13-33.

Pallis, A. A., Vitsounis, T. K., De Langen, W. P., \& Notteboom, T. (2011). Port economics, policy and management: Content classification and survey. Transport Reviews, 31(4), 445-471.

Pettit, S. J., \& Beresford, A. K. C. (2009). Port development: From gateways to logistics hubs. Maritime Policy \& Management, 36(3), 253-267.

Porter, M.E. (1985). The competitive advantage: Creating and sustaining superior performance. New York: Free Press, (Republished with a new introduction, 1998).

Porter, M. E. (1990). The competitive advantage of nations. New York: Free Press.

Porter, M. E. (2000). Location, clusters, and company strategy. In G. Clark, G. M. Gertler, \& M. Feldman (Eds.), Oxford handbook of economic geography (pp. 253-274). Oxford, UK: Oxford University Press. 
Qiong, L., Jie, Y., \& Jinfang, Z. (2011). Application of clustering algorithm in intelligent transportation data analysis. In M. Zhu (Ed.), Information and management engineering (pp. 467-473). Heidelberg: Springer.

Robinson, R. (2002). Ports as elements in value-driven chain systems: The new paradigm. Maritime Policy \& Management, 29(3), 21-40.

Sharman, B. W., \& Roorda, M. J. (2011). Analysis of freight global positioning system data: Clustering approach for identifying trip destinations. Transportation Research Record: Journal of the Transportation Research Board, 2246, 83-91.

Singh, N., Lai, K., \& Cheng, T. C. E. (2007). Intra-organizational perspectives on IT-enabled supply chains. Communications of the $A C M, 50(1), 59-65$.

Tae-Woo Lee, P., \& Venus Lun, Y. H. (2016). Maritime logistics and port connectivity in the globalised economy. Transportation Research Part E, 95(3), 323-325.

Tang, L. C., Low, J. M. W., \& Lam, S. W. (2011). Understanding port choice behavior-A network perspective. Networks and Spatial Economics, 11(1), 65-82.

Tran, N. K. (2011). Studying port selection on liner routes: An approach from logistics perspective. Research in Transportation Economics, 32(1), 39-53.

Turkensteen, M., \& Klose, A. (2012). Demand dispersion and logistics costs in one-to-many distribution systems. European Journal of Operational Research, 223(2), 499-507.

Twrdy, E., Trupac, I., \& Kolenc, J. (2012). Container boom in the port of Koper. Prometheus, 24(2), 169-175.

Vaghi, C., \& Lucietti, L. (2016). Costs and benefits of speeding up reporting formalities in maritime transport. Transportation Research Procedia, 14, 213-222.

Wang, G. W. Y., Zeng, Q., Li, K., \& Yang, J. (2016). Port connectivity in a logistic network: The case of Bohai Bay, China. Transportation Research Part E, 95, 341-354.

Wang, X., \& Cheng, T. C. E. (2009). Logistics scheduling to minimize inventory and transport costs. International Journal of Production Economics, 121(1), 266-273.

Wilmsmeier, G., Hoffman, J., \& Sanchez, R. (2006). The impact of port characteristics on international maritime transport cost. Research in. Transport Economics, 16(1), 117-140.

Wilmsmeier, G., \& Hoffmann, J. (2008). Liner shipping connectivity and port infrastructure as determinants of freight rates in the Caribbean. Maritime Economics and Logistics, 10(1), 130-151.

Yang, Y.-C., \& Chen, S.-L. (2016). Determinants of global logistics hub ports: Comparison of the port development policies of Taiwan, Korea and Japan. Transport Policy, 45(1), 179-189.

\section{Submit your manuscript to a SpringerOpen ${ }^{\circ}$ journal and benefit from:}

- Convenient online submission

- Rigorous peer review

- Open access: articles freely available online

- High visibility within the field

- Retaining the copyright to your article 